\title{
PEMANFAATAN DARAH SISA TRANSFUSI DALAM PEMBUATAN MEDIA BAP UNTUK PERTUMBUHAN BAKTERI Streptococcus pyogenes
}

\author{
Nurhidayanti $^{1}$ \\ ${ }^{1}$ Program Studi DIV Teknologi Laboratorium Medis \\ STIKes Muhammadiyah Palembang \\ e-mail: nuri89_yanti@yahoo.com
}

\begin{abstract}
Streptococcus pyogenes bacteria causes infectious diseases in the respiratory tract. Gold standard for the diagnosis of diseases caused by Streptococcus pyogenes is culture. The special media used is blood agar media. Blood agar media contains special nutrients for bacterial growth, which are enriched with animal or human blood. In Indonesia, wool sheep blood is not easy to obtain, because it is difficult to breed and cannot live adapt to the tropical climate. The alternative is to use human blood as an essential compound for making blood agar media (Abdat, 2010). Based on interviews with several nurses in the hospital there is a phenomenon of blood loss caused by transfusion reactions in patients, so that blood cannot be used anymore. The existence of this phenomenon researchers are interested in conducting research on the utilization of transfusion residual blood that is used as raw material for the manufacture of BAP media in isolation of the growth of the bacteria Streptococcus pyogenes. The number of Streptococcus pyogenes bacterial colonies growing in the media so that sheep blood reaches 170 while in the media so that humans only reach 143 and more colonies that grow in the media so that sheep blood because the blood used is still fresh, so the blood component is still intact, like hemoglobin and erythrocytes haven't died yet.
\end{abstract}

Keywords: Blood Transfusion, Streptococcus pyogenes, and BAP

\begin{abstract}
ABSTRAK
Bakteri Streptococcus pyogenes menyebabkan penyakit infeksi di saluran pernapasan. Gold standard diagnosis penyakit akibat Streptococcus pyogenes adalah kultur. Media khusus yang digunakan adalah media agar darah. Media agar darah mengandung nutrisi khusus untuk pertumbuhan bakteri, yang diperkaya dengan darah hewan atau manusia. Di Indonesia, darah domba wol tidak mudah didapatkan, karena sulit dikembangbiakkan dan tidak dapat hidup beradaptasi dengan iklim tropis. Alternatifnya digunakan darah manusia sebagai senyawa esensial untuk pembuatan media agar darah (Abdat, 2010). Berdasarkan wawancara terhadap beberapa perawat di rumah sakit terdapat fenomena pembuangan darah yang disebabkan reaksi transfusi pada pasien, sehingga darah tidak dapat dipergunakan lagi. Adanya fenomena ini peneliti tertarik untuk melakukan penelitian tentang pemanfaatan darah sisa transfusi yang digunakan untuk bahan baku pembuatan media BAP pada isolasi pertumbuhan bakteri Streptococcus pyogenes.Metode penelitian yang digunakan adalah eksperimental dimana perbedaan jumlah koloni Streptococcus pyogenes pada media agar darah domba dan darah manusia. Jumlah koloni bakteri Streptococcus pyogenes yang tumbuh di media agar darah domba mencapai 170 sedangkan pada media agar manusia hanya mencapai 143 dan lebih banyak koloni yang tumbuh di media agar
\end{abstract}


darah domba karna darah yang digunakan masih dalam keadaan segar, sehingga komponen darah masih dalam keadaan utuh, seperti hemoglobin dan eritrosit belum mati.

Kata Kunci: Darah Transfusi, Streptococcus pyogenes, dan BAP

\section{PENDAHULUAN}

Penyakit infeksi terkait pelayanan kesehatan atau Healthcare Associated Infection (HAIs) merupakan salah satu masalah kesehatan diberbagai negaradi dunia, termasuk Indonesia. Dalam forum Asian Pasific Economic Comitte (APEC) atau Global health Security Agenda (GHSA) penyakit infeksi terkait pelayanan kesehatan telah menjadi agenda yang di bahas (KEMENKES, 2017).

ISPA (Infeksi Saluran Pernafasan Akut) merupakan penyakit infeksi akut yang menyerang salahsatu bagian atau lebih dari saluran nafas mulai dari hidung (saluran atas) hingga alveoli(saluran bawah) termasuk jaringan adneksanya seperti sinus, rongga telinga tengah dan pleura (Irianto, 2015). Bakteri Streptococcus pyogenes dapat menyebabkan penyakit infeksi di saluran pernapasan.Umumnya penyakit yang disebabkan oleh bakteri ini yaitu faringitis, pada kulit bakteri ini dapat menyebabkan selulitis, erisepelas, impetigo, dan pioderma, pada ginjal menyebabkan glomerulonefritis akut, pada otot dan pada katup jantung menyebabkan rheumatic fever.

Pengendalian penyakit akibat infeksi Streptococcus pyogenes memerlukan tatalaksana diagnosis dan penanganan kasus yang tepat. Gold standard diagnosis penyakit akibat Streptococcus pyogenes adalah dengan cara kultur. Pertumbuhan Streptococcus pyogenes memerlukan media yang kompleks, pada lingkungan dan nutrisi tertentu sehingga diperlukan media khusus untuk mengkultur bakteri tersebut. Media khusus yang dapat digunakan untuk menumbuhkan bakteri ini adalah media agar darah. Media agar darah mengandung nutrisi khusus untuk pertumbuhan bakteri, yang diperkaya dengan darah hewan atau manusia. Media tersebut dapat digunakan untuk meningkatkan pertumbuhan Streptococcus pyogenes. Di negaranegara maju, media agar darah domba dan agar darah kuda menjadi media agar darah standar untuk menumbuhkan bakteri yang menggunakan media darah.

Di Laboratorium Amerika Utara, darah domba defibrinasi dijadikan sebagai suplemen darah paling efisien untuk pembuatan media agar dan digunakan sebagai standar untuk mendefinisikan reaksi hemolitik. Di Eropa darah kuda sering digunakan untuk pembuatan media agar darah. Darah kuda banyak mengandung faktor $\mathrm{V}$ (piridin nukleotida) maka darah ini lebih baik untuk pertumbuhan Haemophilus haemolyticus, sedangkan untuk pertumbuhan kuman lainya, seperti Streptococcus sp lebih baik menggunakan darah domba, terutama untuk mengamati adanya hemolisis, sehingga darah kuda direkomendasikan sebagai pilihan kedua.

Darah domba wol (Wool Sheep) dinegara seperti Indonesia tidak mudah didapatkan, karena domba wol sulit dikembangbiakkan dan tidak dapat hidup beradaptasi dengan iklim tropis seperti iklim di Indonesia. Oleh karena itu, sebagai alternatif digunakan darah manusia sebagai senyawa esensial untuk pembuatan media agar darah (Abdat, 2010).

Kenyataan dilapangan juga terdapat beberapa faktor penyebab sulitnya untuk mendapat darah manusia, diantaranya 
karena keterbatasan stok darah dibank darah. Sesuai dengan panduan dari WHO, kebutuhan darah seharusnya dipenuhi $100 \%$ dari donor sukarela, namun yang terjadi donor sukarela baru menutup kebutuhan sebesar $80 \%$ saja. Penggunaan darah stok lebih diperuntukan untuk pasien dirumah sakit. Berdasarkan wawancara terhadap beberapa perawat di rumah sakit terdapat fenomena pembuangan darah yang disebabkan reaksi transfusi pada pasien, sehingga darah tidak dapat dipergunakan lagi. Angka kejadian reaksi transfusi nonhemolisis akut bervariasi hingga 38\% dari seluruh transfusi sel darah merah. Reaksi yang sering terjadi adalah demam nonhemolisis $1,7 \%-30 \%$ dan reaksi alergi $1 \%$ $3 \%$, angka ini menunjukan ada banyak juga darah yang terbuang akibat dari reaksi transfusi. Dengan adanya fenomena ini maka peneliti tertarik untuk melakukan penelitian tentang pemanfaatan darah sisa transfusi untuk digunakan sebagai bahan baku pembuatan media BAP untuk isolasi pertumbuhan bakteri Streptococcus pyogenes.

\section{BAHAN DAN METODE}

Penelitian ini dilakukan di Laboratorium Mikrobiologi STIKes Muhammdiyah Palembang pada tanggal 29 - 31 Mei 2019. Sampel yang digunakan dalam penelitian ini yaitu darah sisa transfusi dan darah manusia. Jenis penelitian yang digunakan dalam penelitian ini adalah perbedaan jumlah koloni Streptococcus pyogenes pada media agar darah domba dan darah manusia adalah eksperimental. Metode penelitian ini menggunakan desain Trueexperimental post test only control group.

\section{HASIL DAN PEMBAHASAN}

Tabel 1. Hasil Uji Kualitas Media, Kesuburan Media dan Sterilitas NaCl

\begin{tabular}{|c|c|c|c|}
\hline Pengujian & Media & Hasil & Keterangan \\
\hline \multirow{2}{*}{$\begin{array}{l}\text { Uji Kualitas } \\
\text { Media }\end{array}$} & Agar Darah Domba & Tidak Tumbuh & Media Steril \\
\hline & $\begin{array}{ll}\text { Agar Darah Sisa } \\
\text { Transfusi }\end{array}$ & Tidak Tumbuh & Media Steril \\
\hline Uji Sterilitas & $\mathrm{NaCl}$ & Tidak Tumbuh & Nacl Steril \\
\hline \multirow{2}{*}{$\begin{array}{l}\text { Uji } \\
\text { Kesuburan }\end{array}$} & Agar Darah Domba & Tumbuh & Media Subur \\
\hline & $\begin{array}{ll}\text { Agar Darah Sisa } \\
\text { Transfusi }\end{array}$ & Tumbuh & Media Subur \\
\hline
\end{tabular}


Berdasarkan tabel 1 diatas hasil uji yang dilakukan antara lain uji kualitas media dan sterilitas $\mathrm{NaCl}$. Diketahui bahwa uji kualitas pada media darah domba dan media darah manusia adalah media steril yang artinya tidak terkontaminasi. Pada uji sterilitas $\mathrm{NaCl}$ adalah steril. Kemudian dilakukan uji kesuburan pada media agar darah domba dan media agar darah sisa transfusi adalah media subur yang artinya kultur koloni bakteri streptococcus pyogenes tumbuh subur pada media tersebut.

a. Uji Normalitas

Uji normalitas ini bertujuan untuk megetahui data yang didapatkan terdistribusi normal atau tidak. Pada tabel dibawah ini dapat dilihat hasil uji normalitas data menggunakan uji shapiro-wilk.

Tabel 2. Hasil Uji Normalitas Data

\begin{tabular}{|c|c|c|c|c|}
\hline \multirow{2}{*}{ Media } & & \multicolumn{3}{|c|}{ Shapiro-Wilk } \\
\hline & & Statistic & Df & Sig. \\
\hline \multirow{2}{*}{$\begin{array}{l}\text { Jumlah } \\
\text { Koloni }\end{array}$} & 1 "media agar darah domba" & .638 & 30 & .060 \\
\hline & 2 "media agar darah sisa transfusi " & .968 & 30 & .490 \\
\hline
\end{tabular}

Berdasarkan tabel 2 di atas hasil uji normalitas data dapat dibuktikan bahwa Ho diterima, maka dapat disimpulkan bahwa data terdistribusi normal. Pada uji signifikan didapatkan nilai $\mathrm{p}$ untuk media $0,00>0,05$ berdasarkan nilai tersebut maka dapat dikatakan bahwa data jumlah koloni pada media agar darah domba dan agar darah sisa transfusi terdistribusi normal.

Tabel 3. Hasil Uji T Tidak Berpasangan

\begin{tabular}{llll}
\hline Media & Mean & SD & $\boldsymbol{P}$ \\
\hline Media agar darah domba & 170 & 22,17 & 0,000 \\
Media agar darah manusia & 143 & & \\
\hline
\end{tabular}

Berdasarkan tabel 3. diatas, hasil uji statistik dengan menggunakan uji T tidak berpasangan diperoleh jumlah koloni pada media agar darah domba sebanyak 170 koloni sedangkan jumlah koloni pada media agar darah sisa transfusi adalah 143 dengan standar deviasi 22,17. Nilai $p$ yang didapat 0,000 artinya secara statistik terdapat perbedaan bermakna antara jumlah koloni bakteri pada media agar darah domba dan media agar darah sisa transfusi.

\section{b. Uji T tidak berpasangan}

Uji T tidak berpasangan digunakan untuk mengetahui perbedaan rata-rata antara dua kelompok berbeda yaitu pada media agar darah domba dan media agar darah sisa transfusi. Setelah dilakukan uji $\mathrm{T}$ tidak berpasangan didapatkan:
Media agar merupakan media yang mengandung glukosa atau karbohidrat yang difermentasikan yang dapat mengubah jenis hemolisis yang dihasilkan, pembuatan media agar darah dengan menambahkan 5\% darah domba atau sisa darah transfusi ke dalam media agar darah (Sonnenwirth et al.,1980).

Pembuatan media agar darah domba menggunakan blood agar base kemudian ditambahkan 5\% darah domba (Russel et al.,2006). Media agar darah domba mampu dengan baik 
menumbuhkan bakteri dikarenakan morfologi dan komposisi dari eritrosit yang dimiliki domba. Darah domba memiliki diameter eritrosit lebih kecil dan juga membrane sel darah pada darah domba lebih tipis dibandingkan eritrosit yang dimiliki oleh darah pada manusia.

Agar darah manusia (sisa transfusi) dibuat dari whole blood di dapatkan dari bank darah yang tidak dapat digunakan lagi atau bisa juga dari pendonor yang suka rela memberikan darahnya, kemudian pembuatan media agar darah manusia sama halnya dengan pembuatan media agar darah domba. Agar darah manusia cenderung banyak dipakai di Negara berkembang termasuk Indonesia karena lebih mudah dalam menyiapkannya dan lebih ekonomis dibandingkan dengan darah domba (Magbojos, 2011).

Penelitian ini dilakukan untuk mengetahui perbedaan jumlah koloni bakteri Streptococcus pyogenes di media agar darah manusia dan di media agar darah domba. Untuk mendapatkan biakan murni bakteri yang ingin ditumbuhkan perlu mensterilakan alat yang akan digunakan. Sterilisasi perlu dilakukan untuk semua tindakan diagnose mikrobiologi terutama membebaskan alat-alat atau bahan dari mikroba yang tidak diharapkan. Hal ini perlu agar hanya biakan murni saja yang terisolasi dan bebas dari kontaminasi mikroba lain. Biakan murni merupakan biakan yang hanya terdapat satu spesies mikroba atau hasil perbanyakan satu sel mikroba. Pada penelitian ini menggunakan Sterilisasi dengan cara pemanasan menggunakan autoclave.

Hasil pengamatan pertumbuhan bakteri Streptococcus pyogenes adalah berkoloni satu-satu, kecil, bulat, halus, berpigmen putih pada masa inkubasi 24 jam dan berukuran sedang serta berpigmen putih kekuningan pada masa inkubasi 48 jam serta dihitung koloninya. Jumlah koloni bakteri Streptococcus pyogenes di media agar darah domba dan di media agar darah manusia tidaklah jauh berbeda tetapi pada media agar darah domba jumlah koloni mencapai 170 sedangkan pada media agar manusia hanya mencapai 143 dan ternyata lebih banyak koloni yang tumbuh di media agar darah domba disebabkan darah yang digunakan masih dalam keadaan segar, sehingga komponen-komponen darah masih dalam keadaan utuh, seperti hemoglobin dan eritrosit belum mati.

Menurut Ellen dkk (2009), darah domba yang difibrinasi adalah bahan yang terbaik untuk pembuatan medium agar darah dan akan member zona hemolysis yang sempurna. Jumlah koloni Streptococcus pyogenes yang tumbuh pada media agar darah manusia tidak berbeda, mungkin disebabkan karena darah sisa transfusi yang digunakan masih mengandung nutrisi dan factor pertumbuhan yang cukup untuk pertumbuhan dan perkembangbiakan kuman. Menurut Beutler dan Srivastava (1980) dan Hall (2006) eritrosit mengandung nutrisi dan factor pertumbuhan yang sangat kompleks bagi kuman-kuman "fastidius" yaitu sekitar 27 macam asam amino, berbagai vitamin antara lain: tiamin, riboflavin, peridoksin, nikotinamid, asam pentotenat, dan vitaman $\mathrm{C}$, serta berbagai nukleotida.

Berdasarkan hasil uji statistik pada penelitian ini didapatkan perbedaan bermakna pertumbuhan darah domba dan darah sisa transfusi. Hal ini dapat disebabkan penggunaan sitrat pada darah sisa transfusi (darah manusia) yang digunakan untuk pembuatan media agar darah dapat menghambat pertumbuhan beberapa jenis bakteri patogen, termasuk bakteri Streptococcus pyogenes. Selain itu darah sisa transfusi mengalami masa simpan yang cukup lama. Pada darah sisa transfusi kadar ATP akan menurun perlahan-lahan, sehingga persedian energinya makin berkurang. Hal ini akan menyebakan pompa $\mathrm{K}-\mathrm{Na}$ tidak 
berfungsi dan $\mathrm{K}$ akan bocor dari eritrosit sehingga menyebabkan lisis. Dengan lisisnya sebagian eritrosit menyebabkan hemoglobin keluar dari sel, dan ini akan menyebabkan sumber nutrisi bagi pertumbuhan bakteri akan berkurang, karena lisisnya eritrosit.

Sebenarnya penggunaan darah dalam medium lebih baik menggunakan darah manusia, karena darah manusia kaya akan nutrisi bagi pertumbuhan bakteri. Di samping itu, darah manusia merupakan hospes bagi bakteri pathogen untuk menimbulkan infeksi Shulman dkk., 1994; Mudatsir dkk., 1999). Tetapi penggunaan darah manusia untuk pembuatan medium agar darah menemui beberapa kendala, seperti sulit mendapatkan darah donor karena lebih diutamakan untuk kepentingan kemanusiaan, oleh karena itu darah domba masih tetap dipertahankan penggunannya untuk medium biakan. Untuk mendapatkan darah domba diperlukan pengadaan domba sendiri dan sarana pemeliharaan, hal ini merupakan masalah tersendiri bagi beberapa laboratorium. Di samping itu saat ini telah ada darah domba yang difibrinasi dijual secara komersial dipasaran umum namun harganya masih sangat mahal (Andrew dkk, 2007). Pada sisi lain darah sisa transfusi pengadaannya lebih praktis dan murah, karena darah kadaluarsa selalu tersedia di bank-bank darah Palang Merah Indonesia (PMI) setempat.

Hasil penelitian ini tidak sejalan dengan hasil penelitian dari Fawzia, dkk (2018) tentang perbedaan jumlah koloni bakteri Streptococcus pyogenes di media agar darah manusia dan darah domba dengan metode pendekatan Post Test Only. Hasil dari pengamatan pertumbuhan koloni menunjukkan bahwa tidak adanya pertambahan kuantitas koloni di kedua media. Selain itu, tidak terdapat perbedaan bermakna kuantitas koloni di kedua media. Hal ini sejalan dengan penelitian Russell pada tahun
2006 yang mendapatkan hasil Streptococcus pyogenes yang ditanam di media agar darah manusia standar tidak ada perbedaan bermakna dalam hal jumlah koloni dengan yang ditumbuhkan di agar darah domba. Tetapi pada penelitian Titiek Djannatun, dkk jumlah koloni bakteri Streptococcus pyogenes lebih banyak di media agar darah manusia di bandingkan dengan media agar darah domba. Karena bakteri Streptococcus pyogenes untuk pertumbuhannya tidak membutuhkan darah tetapi penambahan darah pada media akan menambah nutrisi, sehingga bakteri akan tumbuh subur. Hasil penelitian menunjukkan kemampuan media ADP (darah manusia kadaluwarsa maupun sebelum kadaluwarsa) mengisolasi bakteri lebih baik dibandingkan media ADP (darah domba). Hal ini mungkin karena darah manusia mengandung nutrisi untuk pertumbuhan bakteri tersebut lebih banyak dibandingkan darah domba. Oleh karena itu pengolahan sentrifugasi akan mengurangi nutrisi dalam darah dan menurunkan kemampuan media mengisolasi bakteri.

\section{KESIMPULAN}

Dari hasil pengamatan dapat dilihat bahwa jumlah koloni bakteri Streptococcus pyogenes yang tumbuh di media agar darah domba dan di media agar darah manusia tidaklah jauh berbeda tetapi pada media agar darah domba jumlah koloni mencapai 170 sedangkan pada media agar manusia hanya mencapai 143 dan ternyata lebih banyak koloni yang tumbuh di media agar darah domba mungkin karna disebabkan darah yang digunakan masih dalam keadaan segar, sehingga komponen-komponen darah masih dalam keadaan utuh, seperti hemoglobin dan eritrosit belum mati. Dengan demikian dapat disimpulkan bahwa darah sisa transfusi masih dapat digunakan sebagai pengganti darah 
domba untuk menumbuhkan bakteri Streptococcus pyogenes.

\section{DAFTAR PUSTAKA}

Abdat, A. 2010. Pertumbuhan Streptococcus pneumoniae Pada Agar Darah Manusia dan Agar Darah Domba. Artikel Ilmiah. Fakultas Kedokteran Universitas Diponogoro Semarang.

Andrew, L. Stanley, M. Reller, L.B and Melvin, P. W. 2007. Detection Of Bloodstream Infection In Adults; How Many Blood Cultures Are Needed? J. Clin Microbiol. 45: 35463548 .

Beutler, E. Dan SK Srivastava. 1980. Composition of The Erythrocyte. In Wiliam J.E,. Beutler, E. Hematology. Second Edition. McGraw-Hill Book Company. USA. 135-139.

Ellen, Y., Benjamin, A., Pinsky, L., Niaz, B., Ellen, J, B. 2009. Hair Sheep Blood, Citrated or Defibrinated, Fulfills All Requirements Of Blood Agar For Diagnostic Microbiology Laboratory Tests PloS ONE. 4: 1-8.

Fawzia, N. Hadi, P., dan Farida, H. 2018. Perbandingan pertumbuhan Streptococcus pneunomiae pada media agar darah domba dan darah manusia Pengaruh Preinkubasi Dalam Suplemented Todd Hewitt Broth (STHB). Jurnal Kedokteran Diponogoro. Vol. 7 (2): 711-723.

Hall, KK. 2006. Update Review Of Blood Culture Contamination. Clin Microbiol Rev. 19: 788-802.

Irianto, K (2015). Bakteriologi Medis, Mikologi Medis, Virologi Medis. Bandung: Alfabeta, pp: 2; 54;107.
KEMENKES. 2017. Permenkes No. 27 Tahun 2017 tentang Pedoman Pencegahan dan Pengendalian Infeksi di Fasilitas Pelayanan Kesehatan. Indonesia

Magbojos, CR, Richelle SA, MA Charisma SC, Melvin MC, Darwin Al, Karen D. 2011. Preparation of the blood- enriched agar with the use of red cell suspension. Asian $J$ Health. Vol 1(1): PP. 259-275.

Mudatsir. 2012. Penggunaan Darah Kadarluarsa Sebagai Media Isolasi dan Identifikasi Streptococcus faecalis. Surabaya

Russel, FM, Biribo SS, Selvaraj G, Oppedisano F, Warren S, Seduadua A, el al. 2006. As a bacterial medium, citrated hair sheep blood agar is a practical alternative to citrated human blood agar in laboratories in developing countries. J Clin Microbiol. 44: 3346-3351

Shulman, S.T. 1994. Dasar Biologi dan Klinis Penyakit Infeksi. Edisi Keempat. Penerjemah; Wahab, AS. Gajah Mada University Press. Yogyakarta. 106-121.

Sonnenwirth AC, Jarret L. 1980. Gradwohl's Clinical Laboratory Methods and Diagnosis. Edisi Ke-8, pp : 1339-1340; 1344-1348; 16321642. 